\title{
Pengaruh Bobot Biji terhadap Pertumbuhan Semai Petai (Parkia speciosa Hassk.)
}

\author{
The Effect of Seed Weight on Growth of Stink Bean (Parkia speciosa Hassk.) Seedlings
}

\section{Ni L.P. Indriyani*, Deni Emilda}

Balai Penelitian Tanaman Buah Tropika, J1 Raya Solok-Aripan Km 8 Solok 27301, Sumatera Barat, Indonesia

*E-mail Penulis Korespondensi: nlp_indriyani@yahoo.co.id

Tanggal submisi: 18 Februari 2020; Tanggal penerimaan: 17 Juni 2020

\begin{abstract}
One of the horticultural commodities included in the national seed provision program in 2018 is a stinking bean. The aim of the research was to determine the effect of seed weight on stink bean seedling growth. The research was conducted at Sumani Research Station, Indonesian Tropical Fruit Research Institute, from September to December 2017. A Complete Randomized Block Design was used in this study consisted of 5 treatments and 4 replications. The treatments were stink bean seed weights, namely: A) 1.5-1.8 g; B) 1.9-2.2 g; C) 2.3-2.6 g; D) 2.7-3 g; and E) > $3 \mathrm{~g}$. The observed variables were plant height, stem diameter, leaf number, leaflet number, total dry weight of plants, length of roots, and a number of living seedlings. Data analysis used analysis of variance (ANOVA) and was proceeded with HSD test at $\alpha 5 \%$ if these treatments given gave significantly different effects. The results showed that the stink bean seed weight significantly affected the growth parameters of seedlings, including plant height, stem diameter, leaflet number, dry weights (of roots, upper parts of plants, and total) at 12 weeks after sowing. The seedlings from seeds weighing $>3 \mathrm{~g}$ had the highest plant height, stem diameter, leaflet number, and dry weight (of roots, upper parts of plants, and total) compared to those seedlings from smaller seeds.
\end{abstract}

Keywords: stink bean, seed weight, seedling growth

\section{ABSTRAK}

Salah satu komoditas hortikultura yang termasuk dalam program perbenihan nasional pada tahun 2018 adalah petai. Penelitian bertujuan untuk mengetahui pengaruh bobot biji terhadap pertumbuhan semai petai. Penelitian dilakukan di KP Sumani, Balai Penelitian Tanaman Buah Tropika, mulai bulan September sampai Desember 2017. Penelitian menggunakan rancangan acak kelompok lengkap dengan lima perlakuan dan empat ulangan. Perlakuan adalah bobot biji petai, yaitu: A) 1,5-1,8 g; B) 1,9-2,2 g; C) 2,3-2,6 g; D) 2,7-3 g; dan E) > 3 g. Peubah yang diamati adalah tinggi tanaman, diameter batang, jumlah daun, jumlah anak daun, bobot kering total tanaman, panjang akar dan jumlah benih hidup. Data dianalisis dengan menggunakan analisis ragam dan dilanjutkan dengan uji beda BNJ 5\% jika perlakuan yang diberikan memberikan pengaruh yang nyata. Penelitian menunjukkan bahwa bobot biji petai berpengaruh nyata terhadap parameter pertumbuhan, seperti tinggi tanaman, diameter batang, jumlah anak daun, bobot kering (akar, bagian atas tanaman dan total) pada umur 12 minggu setelah semai. Semaian dari biji dengan bobot $>3 \mathrm{~g}$ mempunyai tinggi tanaman, diameter batang, jumlah anak daun dan bobot kering (akar, bagian atas tanaman dan total) yang terbesar dibandingkan bibit-bibit dari biji-biji yang lebih kecil.

Kata kunci: bobot biji, pertumbuhan bibit, petai

\section{PENDAHULUAN}

Tahun 2018 telah dicanangkan sebagai tahun perbenihan oleh Kementerian Pertanian. Untuk hortikultura, salah satu tanaman yang menjadi prioritas adalah petai. Petai merupakan tanaman sayuran yang berupa tanaman tahunan. Tanaman petai (Parkia speciosa Hassk.) banyak dijumpai di Indonesia, Malaysia, Thailand dan Filipina. Dalam 100 gr bagian yang dapat dimakan, biji petai mengandung 6-27,5 g protein, 1,6-13,3 g lemak, 13,2-52,9 g karbohidrat, 108265,1 mg kalsium, $341 \mathrm{mg}$ kaliunm, 19,3 mg vitamin C (Maisuthisakul et al., 2008 and Hong et al., 2004 dalam Kamisah et al., 2013).

Perbanyakan petai yang selama ini biasa dilakukan adalah dengan perbanyakan generatif yaitu melalui biji. Cara ini akan menghasilkan benih yang beragam. Untuk itu, dianjurkan melakukan perbanyakan vegetatif melalui penyambungan sehingga benih yang diperoleh true to type dengan induknya. Perbanyakan 
dengan biji diperlukan untuk penyediaan batang bawah. Menurut Mirgal et al. (2016) dan Gunagu and Vasudeva (2011). Produksi batang bawah yang berkualitas tergantung pada beberapa faktor, salah satunya adalah ukuran biji yang memengaruhi perkecambahan dan kevigoran batang bawah. Batang bawah yang vigor merupakan salah satu penentu keberhasilan penyambungan. Dari observasi yang dilakukan pada $2 \mathrm{~kg}$ petai (731 biji petai yang sehat) diperoleh biji dengan bobot 1,5-1,8 g sebanyak $12,2 \%$; bobot $1,9-2,2 \mathrm{~g}$ sebanyak 19,8\%; bobot 2,3-2,6 g sebanyak 31\%; bobot 2,7-3 g sebanyak $23 \%$ dan bobot $>3$ g sebanyak $14 \%$.

Peranan bobot biji pada pertumbuhan benih telah banyak dipelajari pada berbagai komoditas. Semai Prunus jenkinsii Hook.f.\&Thoms. yang tumbuh dari biji yang bobot (> $2 \mathrm{~g}$ ) mempunyai pertumbuhan yang lebih baik dibandingkan dengan biji dari bobot sedang (1,5-2 g) dan ringan (1,5 g) (Uphadaya, 2007). Penggunaan biji manggis dengan bobot termasuk kategori berat (> 1,6 g) pada umur 4 bulan menghasilkan semai manggis paling tinggi, jumlah daun dan diameter batang paling besar dibandingkan penggunaan biji dengan bobot agak berat $(1,21-1,6 \mathrm{~g})$, sedang $(0,8-1,2 \mathrm{~g})$ dan ringan $(<0,8$ g) (Anwaruddin et al., 2003). Penggunaan biji Parkia timoriana (DC.) Merr. dengan bobot $>1 \mathrm{~g}$ memberikan perkecambahan biji, semai hidup, pertumbuhan dan akumulasi biomassa yang lebih baik dibandingkan dengan bobot biji 0,8 g dan 0,8-1 g (Yumnam, 2015). Sejauh ini, untuk petai belum ada informasi mengenai pengaruh bobot biji pada pertumbuhan semai.

Penelitian bertujuan untuk mengetahui pengaruh bobot biji terhadap pertumbuhan semai petai (Parkia speciosa Hassk.).

\section{BAHAN DAN METODE}

Penelitian dilakukan di KP. Sumani, Balai Penelitian Tanaman Buah Tropika, mulai bulan September sampai Desember 2017. Penelitian menggunakan Rancangan Acak Kelompok Lengkap dengan 5 perlakuan dan diulang 4 kali. Perlakuan merupakan bobot biji petai, yaitu: 1,5-1,8 g, 1,9-2,2 g, 2,3-2,6 g, 2,7-3 g dan > $3 \mathrm{~g}$.

Bahan tanaman yang digunakan adalah tanaman petai lokal dari Nagari Singkarak, Kecamatan X Koto Singkarak, Kabupaten Solok. Biji petai yang telah matang dibersihkan dari kulit buahnya dan direndam selama 3 jam. Selanjutnya biji ditanam di polibag $(18 \times$ $21 \mathrm{~cm}$ ) dengan campuran media tanah:pupuk kandang
(1:1). Polibag diletakkan di bawah naungan paranet $75 \%$.

Peubah yang diamati adalah tinggi tanaman, diameter batang, jumlah daun, jumlah anak daun, bobot kering (akar, bagian atas tanaman dan total tanaman), panjang akar dan jumlah tanaman hidup. Pengukuran tinggi tanaman dilakukan dari atas tanah sampai titik tumbuh tanaman, diameter batang diukur pada ketinggian $2 \mathrm{~cm}$ dari atas tanah dengan menggunakan jangka sorong. Persentase tanaman hidup (\%) diperoleh dengan membagi jumlah tanaman yang hidup dengan jumlah sampel dikalikan 100\%. Bobot kering tanaman dilakukan secara destruktif dengan mencabut tanaman petai dan membersihkan akarnya dari tanah. Tanaman dipotong pada leher akar untuk memisahkan bagian akar dan bagian atas tanaman, selajutnya dioven selama 3 hari pada suhu $110{ }^{\circ} \mathrm{C}$. Pengukuran panjang akar dilakukan dari leher akar sampai bagian akar yang terpanjang.

Pengamatan tinggi tanaman, diameter batang, jumlah daun dan anak daun dilakukan 2 minggu setelah ditanam dan selanjutnya dilakukan setiap 2 minggu. Pada akhir pengamatan (12 minggu) dilakukan penghitungan tanaman yang hidup, bobot kering dan panjang akar. Pertumbuhan tinggi tanaman, diameter batang, jumlah daun dan jumlah anak daun pada berbagai umur ditampilkan secara deskriptif. Analisa data menggunakan analisis ragam dan jika hasil analisa berbeda nyata maka dilanjutkan dengan uji beda BNJ $5 \%$. Tampilan kelompok bobot biji untuk perlakuan disajikan pada Gambar 1.

\section{HASIL DAN PEMBAHASAN}

Hasil analisa menunjukkan bahwa bobot biji petai pada umur 12 minggu berpengaruh nyata pada pertumbuhan semai petai yaitu tinggi tanaman, diameter batang, dan jumlah anak daun (Tabel 1). Semai yang tertinggi diperoleh dari bobot biji $>3,0 \mathrm{~g}$ dan tidak berbeda nyata dengan semai yang berasal dari biji dengan bobot 2,7-3 g, tetapi berbeda nyata dengan bobot biji lainnya (1,5-1,8 g, 1,9-2,2 g dan 2,3-2,6 g). Diameter batang terbesar diperoleh dari bobot biji $>3,0$ $\mathrm{g}$ dan tidak berbeda nyata dengan diameter batang semai yang berasal dari biji dengan bobot 2,3-2,6 g dan 2,7$3,0 \mathrm{~g}$, tetapi berbeda nyata dengan semai yang berasal dari bobot 1,5-1,8 g dan 1,9-2,2 g. Jumlah anak daun dari semai petai yang berasal dari bobot biji $>3 \mathrm{~g}$ paling banyak dan hanya berbeda nyata dengan jumlah daun dari semai yang berasal dari biji dengan bobot 1,5-1,8 $\mathrm{g}$.

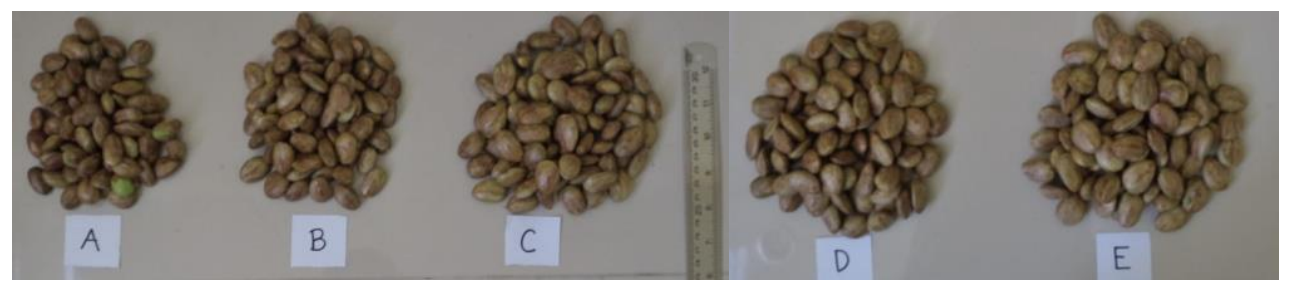

Gambar 1.Kelompok bobot biji petai yang digunakan dalam penelitian ini: A) 1,5-1,8 g; B) 1,9-2,2 g; C) 2,3-2,6 g; D) $2,7-3 \mathrm{~g} ;$ dan E) $>3 \mathrm{~g}$ 
Tabel 1. Pengaruh bobot biji petai terhadap pertumbuhan tanaman petai pada 12 minggu setelah semai

\begin{tabular}{lcccc}
\hline Perlakuan & Tinggi tanaman $(\mathrm{cm})$ & Diameter batang $(\mathrm{cm})$ & Jumlah daun (helai) & Jumlah anak daun (helai) \\
\hline $1,5-1,8 \mathrm{~g}$ & $20,48 \mathrm{a}$ & $5,79 \mathrm{a}$ & $5,08 \mathrm{tn}$ & $47,80 \mathrm{a}$ \\
$1,9-2,2 \mathrm{~g}$ & $23,94 \mathrm{ab}$ & $6,27 \mathrm{ab}$ & 5,14 & $52,67 \mathrm{ab}$ \\
$2,3-2,6 \mathrm{~g}$ & $24,32 \mathrm{ab}$ & $6,34 \mathrm{abc}$ & 4,96 & $51,76 \mathrm{ab}$ \\
$2,7-3 \mathrm{~g}$ & $28,32 \mathrm{bc}$ & $6,78 \mathrm{bc}$ & 5,34 & $55,95 \mathrm{ab}$ \\
$>3 \mathrm{~g}$ & $31,82 \mathrm{c}$ & $6,94 \mathrm{c}$ & 5,20 & $58,21 \mathrm{~b}$ \\
\hline
\end{tabular}

Tabel 2. Pengaruh bobot biji petai terhadap bobot kering (akar, bagian atas dan total tanaman) panjang akar dan jumlah tanaman hidup petai pada 12 minggu setelah semai

\begin{tabular}{|c|c|c|c|c|c|}
\hline \multirow[b]{2}{*}{ Perlakuan } & \multicolumn{3}{|c|}{ Bobot Kering } & \multirow[b]{2}{*}{$\begin{array}{c}\text { Panjang } \\
\text { akar }(\mathrm{cm})\end{array}$} & \multirow[b]{2}{*}{$\begin{array}{l}\text { Tanaman } \\
\text { hidup }(\%)\end{array}$} \\
\hline & $\operatorname{akar}(\mathrm{g})$ & $\begin{array}{l}\text { bagian atas } \\
\operatorname{tanaman}(\mathrm{g})\end{array}$ & total $(\mathrm{g})$ & & \\
\hline $1,5-1,8 \mathrm{~g}$ & $1,29 \mathrm{a}$ & $4,14 \mathrm{a}$ & $5,33 \mathrm{a}$ & $27,31^{\mathrm{tn}}$ & $83,75^{\text {tn }}$ \\
\hline $1,9-2,2 \mathrm{~g}$ & $1,10 \mathrm{a}$ & $4,83 \mathrm{a}$ & 5,93 a & 24,35 & 87,50 \\
\hline $2,3-2,6 \mathrm{~g}$ & $1,41 \mathrm{a}$ & $5,62 \mathrm{ab}$ & $7,02 \mathrm{ab}$ & 28,09 & 95,00 \\
\hline $2,7-3 \mathrm{~g}$ & $1,88 \mathrm{ab}$ & $7,29 \mathrm{bc}$ & 9,16 bc & 31,06 & 98,75 \\
\hline$>3 \mathrm{~g}$ & $2,77 \quad b$ & $7,58 \quad \mathrm{c}$ & $10,34 \quad \mathrm{c}$ & 32,96 & 90,00 \\
\hline
\end{tabular}

Sadjad et al. (1974) menyatakan bahwa bobot suatu benih dipengaruhi oleh kandungan endosperm. Bobot benih akan menentukan kecepatan tumbuh, dimana bobot benih yang tinggi dengan kandungan endosperm yang banyak akan menghasilkan energi yang lebih besar pada saat proses perkecambahan. Selanjutnya Yan et al. (2014) juga menyatakan bahwa endosperm memainkan peranan yang penting dalam mendukung pertumbuhan embrio dengan memasok nutrisi, melindungi embrio dan mengendalikan pertumbuhan embrio dengan bertindak sebagai penghalang mekanik selama perkembangan dan perkecambahan biji.

Hasil analisa ragam menunjukkan bahwa bobot biji berpengaruh nyata terhadap bobot kering akar, bobot kering bagian atas tanaman dan kering total tanaman pada umur 12 minggu setelah semai (Tabel 2). Biji dengan bobot $>3 \mathrm{~g}$ memiliki bobot kering akar, bagian atas tanaman dan total tanaman yang paling tinggi dan tidak berbeda nyata dengan bobot biji 2,7-3 $\mathrm{g}$, tetapi berbeda nyata dengan 3 kelompok lainnya.

Biji duku dengan bobot sedang (1,76-2,75 g) dan berat (> 2,76 g) dapat meningkatkan pertumbuhan tinggi tanaman, diameter batang, panjang akar, jumlah akar dan bobot kering (Susiloadi et al., 1998). Penelitian serupa pada Parkia roxburghii G. Don menunjukkan bahwa ukuran biji berpengaruh nyata terhadap panjang akar, panjang tunas, panjang semai, diameter batang. Biji yang lebih besar mempunyai akar yang lebih panjang (Rana et al., 2017). Hasil penelitian serupa pada tanaman durian juga menyimpulkan bahwa bobot biji terbesar menghasilkan pertumbuhan tanaman yang lebih baik (Ding et al., 2015). Pada tanaman macadamia, pertumbuhan benih terbaik didapatkan pada tanaman yang berasal dari biji ukuran sedang dimana hasilnya tidak berbeda nyata dengan pertumbuhan tanaman asal biji ukuran besar namun berbeda nyata dengan pertumbuhan tanaman asal benih ukuran kecil
(Heryana et al., 2008). Tidak hanya pada tanaman dikotil, pada tanaman monokotil seperti tanaman jagung juga diperoleh hasil yang sama dimana benih asal biji terbesar menghasilkan pertumbuhan benih yang lebih baik dibandingkan benih asal biji yang kecil (Pratama $e t$ al., 2014).

Meskipun pada penelitian lain bobot biji menghasilkan perbedaan panjang akar yang nyata diantara berbagai perlakuan, tetapi pada penelitian ini bobot biji petai menghasilkan panjang akar yang tidak berbeda nyata. Perbedaan bobot kering akar pada berbagai perlakuan kemungkinan disebabkan oleh banyaknya jumlah akar sekunder/akar rambut. Salah satu peristiwa yang penting selama siklus hidup tanaman adalah keberlangsungan hidup perkecambahan. Sampai akhir pengamatan, bobot biji tidak mempengaruhi jumlah tanaman yang hidup. Jumlah tanaman yang hidup berkisar antara $83,75-98,75 \%$. Ini berarti bahwa bobot biji yang kecilpun masih dapat digunakan, akan tetapi memerlukan waktu yang lebih lama untuk mencapai ukuran tanaman seperti tanaman yang berasal dari biji yang besar.

Dari data yang diperoleh didapatkan bahwa pertumbuhan tinggi tanaman, diameter batang, jumlah daun dan anak daun tanaman petai dari berbagai kelompok bobot biji pada umur 1-12 bulan sejak semai cukup beragam (Gambar 2). Pada Gambar 2 terlihat bahwa kelompok biji dengan ukuran terbesar $(\mathrm{E}>3 \mathrm{~g})$ secara umum mempunyai pertumbuhan tinggi tanaman, diameter batang, jumlah daun dan anak daun yang lebih baik dibandingkan dengan kelompok bobot biji lainnya. Hasil serupa diperoleh pada Parkia timoria (DC) Merr. dimana vigor tanaman memperlihatkan hubungan yang positif dengan peningkatan bobot biji dan jumlah hari (Thangjam dan Sahoo, 2016). Pada tanaman Acacia nilotica, terdapat korelasi positif antara bobot biji dengan parameter pertumbuhan dan persentase hidup benih (Missanjoang dan Mkwezalamba, 2015). 


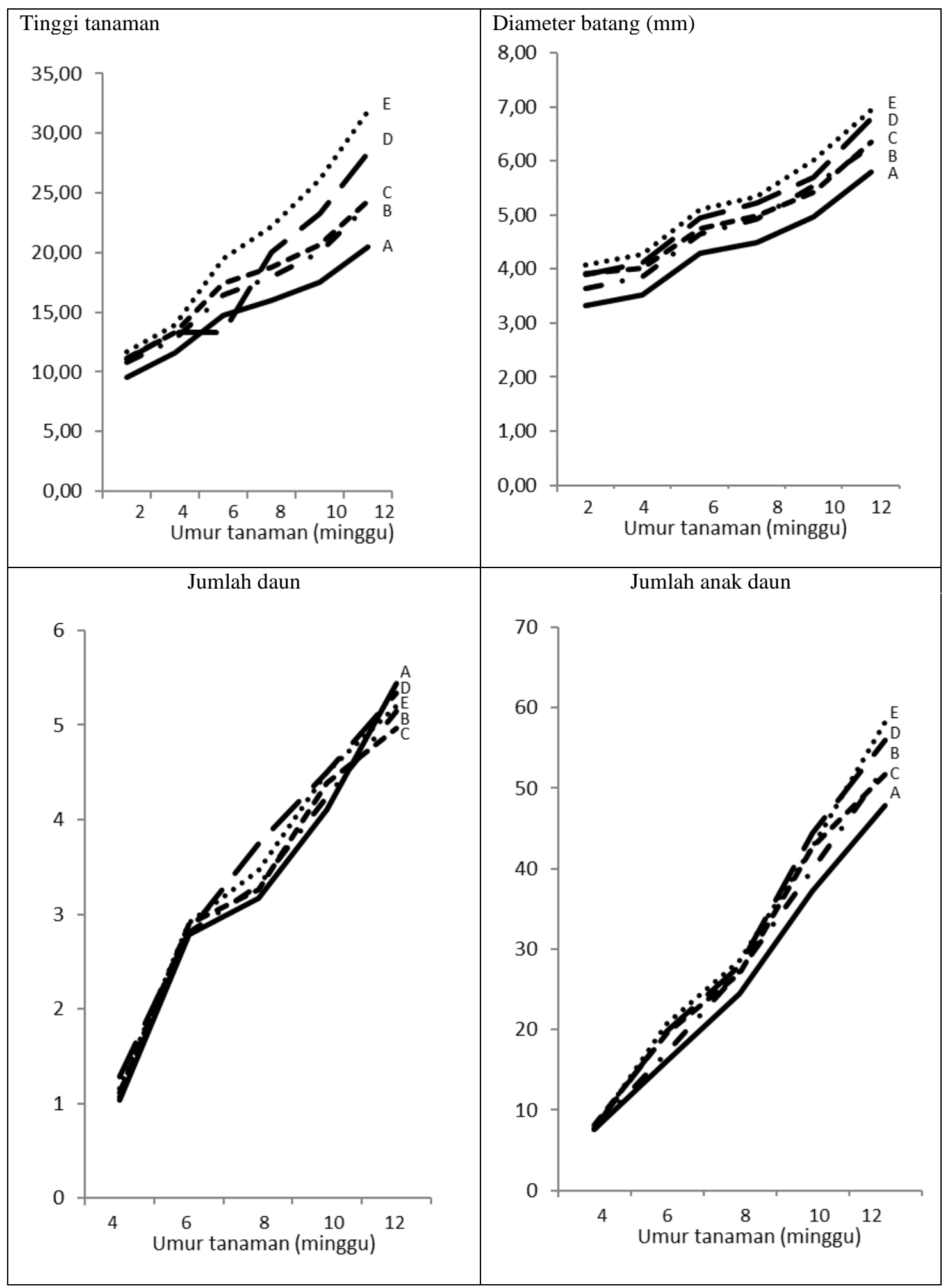

Gambar 2. Pertumbuhan tinggi, diameter batang, jumlah daun dan anak daun tanaman petai pada berbagai kelompok bobot biji

\section{KESIMPULAN}

Bobot biji petai berpengaruh nyata pada pertumbuhan tinggi tanaman, diameter batang, jumlah anak daun, bobot kering (akar, bagian atas tanaman dan total) pada umur 12 minggu setelah semai. Biji dengan bobot > $3 \mathrm{~g}$ mempunyai tinggi tanaman, diameter batang, jumlah anak daun dan bobot kering (akar, bagian atas tanaman dan total) yang terbesar.

\section{DAFTAR PUSTAKA}

Anwaruddin, M.J., T. Purnama, Y. Meldia, dan F. Usman. 2003. Pengaruh bobot biji dan kulit biji 
terhadap perkecambahan dan pertumbuhan bibit manggis. Stigma 9: 47-50.

Ding, T., H. Sutejo, dan A. Patah. 2015. Pengaruh berat benih dan media tanam terhadap pertumbuhan vegetatif bibit durian (Durio zibethinus Murr). Jurnal Agrivor 14: 261-268.

Gunagu, R. and R. Vasudeva. 2011. Influence of Seed Size Germination and Seedling Growth in Mammea suriga. Karnataka Journal of Agriculture Science 24: 415-416.

Heryana, N., R. Rusli, dan G. Indriati. 2008. Pengaruh ukuran benih terhadap pertumbuhan bibit macadamia (Macadamia integrifolia). Jurnal Agrin 12: 35-41.

Kamisah, Y., F. Othman, M.S Qodriyah, and K. Jaarin. 2013. Parkia Speciosa Hassk.: A Potential Phytomedicine. Evid Based Complement Alternat Med. Published online 2013 Jul 17. DOI: $10.1155 / 2013 / 709028$

Mirgal, A.B., R.P. Gunaga, and C.B. Salunke. 2016. Seed size and its influence on germination, seedling growth and biomass in Saraca asoca (Roxb) De Wilde critically endangered tree species of Western Ghats. India Journal of Applied and Natural Science 8: 1599-1602.

Missanjo, E. and I. Mkwezalamba. 2015. Influence of seed weight variation on seedling emergence and growth of Acacia nilotica. Journal of Basic and Applied Research International 2: 85-94.

Pratama, H.W., M. Baskara, dan B. Guritno. 2014. Pengaruh ukuran biji dan kedalaman tanam terhadap pertumbuhan dan hasil tanaman jagung (Zea mays Saccharata Sturt). Jurnal Produksi Tanaman 2: 572-582.
Rana, A., C.L. Leishangthem, H. Kadiri, and B.Ng.N. Ziipoa. 2017. Effect of seed size, pre sowing treatment and potting mixture on the seedling growth of Parkia roxburghii G. Don seeds. International Journal of Current Microbiology and Applied Science 6: 629-638. DOI: 10.20546/ijcmas.2017.608.080

Sadjad, S., M. Purnomohadi, Z. Jusuf, dan Z.A. Pian. 1974. Penuntun Praktikum Teknologi Benih. Institut Pertanian Bogor. Bogor.

Susiloadi, A., M. Jawal, dan N.L.P. Indriyani. 1998. Pengaruh media semai dan bobot biji terhadap perkecambahan dan pertumbuhan semai duku (Lansium domesticum Corr.). Stigma 6: 24-26.

Thangjam, U. and U.K. Sahoo. 2016. Effect of seed mass on germination and seedling vigour of Parkia Timoriana (DC.) Merr. Current Agriculture Research Journal 4: 171-178.

Upadhaya, K., H.N. Pandey, and P.S. Law. 2007. The Effect of Seed Mass on Germination, Seedling Survival Growth in Prunus jenkinsii Hook.f. \& Thoms. Turkish Journal of Botany 31: 31-36.

Yan, D., L. Duermeyer, C. Leoveanu, and E. Nambara. 2014. The functions of the endosperm during seed germination. Plant Cell Physiology 55: 1521-33. DOI: $10.1093 / \mathrm{pcp} / \mathrm{pcu} 089$

Yumnam, J.Y. 2015. The effect of seed weight and size on germination and growth of Parkia timoriana (Dc.) Merr. (Syn. P. Roxburghii G. Don.), a multipurpose tree and a delicious vegetable of Manipur, India. International Journal of Current Research 7: 20744-20749. 